\title{
Lactate Clearance sebagai Prediktor Mortalitas pada Pasien Sepsis Berat dan Syok Septik di Intesive Care Unit Rumah Sakit Dr. Hasan Sadikin Bandung
}

\author{
Muhammad Budi Kurniawan, Erwin Pradian, A. Muthalib Nawawi \\ Departemen Anestesiologi dan Terapi Intensif \\ Fakultas Kedokteran Universitas Padjadjaran/Rumah Sakit Dr. Hasan Sadikin Bandung
}

\begin{abstract}
Abstrak
Tingkat mortalitas pasien sepsis berat di Intensive Care Unit (ICU) dihitung dengan menggunakan skor acute physiology and chronic health evaluation (APACHE II), namun memerlukan pemeriksaan yang banyak serta kompleks. Penurunan lactate clearance berhubungan dengan kondisi mikrosirkulasi yang buruk. Lactate clearance diharapkan memiliki kemampuan untuk menentukan tingkat mortalitas pasien sepsis berat dan syok septik. Penelitian ini bertujuan mengetahui kegunaan lactate clearance sebagai prediktor mortalitas pasien sepsis berat dan syok sepsis di ICU Rumah Sakit Dr. Hasan Sadikin (RSHS) Bandung yang lebih mudah dan efisien. Penelitian ini dilakukan secara prospektif observasional cohort terhadap 51 orang. Penelitian dilakukan di ICU RSHS Bandung dari bulan September-November 2015 dengan uji Mann Whitney pada data numerik dan Exact Fisher pada data kategorik. Setiap subjek penelitian diperiksa nilai laktat secara berkelanjutan pada jam pertama (H0) dan jam ke-24, kemudian dihitung nilai lactate clearance dengan rumus laktat awal-laktat serial/laktat awal x 100\%. Subjek dibagi menjadi 2 kelompok berdasar atas nilai lactate clearance rendah $(<40 \%)$ dan nilai lactate clearance tinggi $(>40 \%)$. Hasil penelitian menunujukkan bahwa lactate clearance memiliki sensisitivitas $100 \%$; spesifisitas $88,4 \%$; nilai duga positif $89,2 \%$; nilai duga negatif $100 \%$; rasio kemungkinan positif $86,6 \%$; rasio kemungkinan negatif 0 dan akurasi $94,11 \%$. Simpulan penilitian adalah lactate clearance dapat digunakan sebagai prediktor mortalitas pada pasien sepsis berat dan syok septik di ICU RSHS Bandung.
\end{abstract}

Kata kunci: Lactate clearance, mortalitas, sepsis

\section{Lactate Clearance as Mortality Predictor in Severe Sepsis and Septic Shock Patient in Intensive Care Unit Dr. Hasan Sadikin General Hospital Bandung}

\begin{abstract}
Mortality incidence predictor used for sepsis and shock septic in Intensive Care Unit (ICU) were measured using Acute Physiology and Chronic Health Evaluation (APACHE) II score, which needs many complex examinations. The purpose of this study was to examine lactate clearance as an alternative mortality predictor. Decreased percentage of lactate clearance is related to poor perfusion in microcirculation which leads to the possibility that lactate clearance can be used to predict mortality incidence in severe sepsis and shock septic patients in the ICU of Dr. Hasan Sadikin General Hospital Bandung. This was a prospective observational cohort study involving 51 patients who met sepsis and shock septic criteria during the period of September to November 2015. Lactate was examined continuously in all patients at first hour (H0) and $\mathrm{H} 24$ and then the lactate clearance value was measured using the following formula: lactate initiallactate delayed/lactate initial $\mathrm{x} 100 \%$. Subjects were divided into two groups according to the low lactate clearance $(<40 \%)$ and high lactate clearance $(>40 \%)$. The Mann Whitney test was used for numeric data and exact Fisher test was used for categorical data. Results showed that the lactate clearance had a sensitivity of $100 \%$, specificity of $88.4 \%$, positive predictive value of $89.2 \%$, negative predictive value of $100 \%$, likelihood ratio positive of $86.6 \%$, likelihood ratio negative of $0 \%$ and accuracy of $94.11 \%$. Thus, lactate clearance can be used to predict mortality incidence in severe sepsis and shock septic patients.
\end{abstract}

Key words: Lactate clearance, mortality, sepsis

Korespondesi: Muhammad Budi Kurniawan, dr., SpAn, Departemen Anestesiologi dan Terapi IntensifFakultas Kedokteran Universitas Padjadjaran/Rumah Sakit Dr. Hasan Sadikin Bandung, Jl. Pasteur No. 38 Bandung 40161, Telp. (022) 2038285, Mobile 08112106022,Email meet_dbudi@yahoo.com 


\section{Pendahuluan}

Sepsis merupakan kondisi penyakit yang berat dan meningkatkan angka morbiditas. Sepsis berat dan syok septik masih menjadi salah satu penyebab utama kematian pasien perawatan intensif di dunia. ${ }^{1}$ Beberapa strategi awal resusitasi pada pasien dengan sepsis berat dan syok sepsis dapat menurunkan angka mortalitas pasien, tetapi dari beberapa data menunjukan bahwa masih banyak pasien dirawat dalam waktu yang lama di Intensive Care Unit (ICU). ${ }^{2}$

Sepsis menjadi penyebab kematian ke-10 di Amerika Serikat saat ini. Insidens sepsis semakin meningkat dan akan terus meningkat seiring dengan peningkatan usia. Setiap tahun diperkirakan 400.000 hingga 500.000 pasien mengalami sepsis di Eropa dan Amerika Serikat. ${ }^{3}$ Keadaan sepsis merupakan kombinasi patofisiologi infeksi dan perubahan fisiologi dengan peningkatan denyut jantung, suhu tubuh, dan napas. ${ }^{4}$ Early goal directed therapy (EGDT) adalah rekomendasi internasional untuk tata laksana sepsis berat dan syok septik, dengan optimalisasi mean arterial pressure (MAP), central venous pressure (CVP), urine output (UOP) dan central venous oxygen $\left(\mathrm{SvO}_{2}\right)$, namun angka mortalitas pada sepsis berat dan syok septik masih tinggi. ${ }^{4}$ Suatu nilai prediksi prognostik pada pasien sepsis berat dan syok septik sangat dibutuhkan untuk menentukan agresivitas terapi yang akan kita pilih. Berbagai cara digunakan untuk memprediksi mortalitas pasien yang dirawat di ruang intensif. ${ }^{5}$ Tanda klinis sepsis biasanya menunjukkan tanda perfusi jaringan yang buruk. Hipotensi berat, oliguria atau anuria, perubahan status mental dan takipnea selalu dijumpai pada asidosis laktat yang disebabkan oleh hipoksemia jaringan. ${ }^{6,7}$

Gambaran klinis pada kondisi hipoperfusi jaringan ditandai dengan terjadinya hipotensi, penurunan kesadaran, dan vasokonstriksi perifer. Parameter hemodinamik global sering kali tidak dapat digunakan sebagai acuan pada pasien kritis dalam keadaan sepsis berat dan syok septik. ${ }^{8}$ Berdasar atas hal tersebut maka diperlukan penanda untuk menilai gangguan perfusi jaringan (shock microcirculation). ${ }^{9}$ Saat terjadi gangguan perfusi jaringan, peningkatan kadar laktat dalam darah merupakan penanda gangguan perfusi jaringan/gagal sirkulasi. ${ }^{10}$

Kadar laktat darah statis telah banyak diteliti untuk dijadikan sebagai nilai prognostik pada pasien sepsis berat dan syok septik karena laktat merupakan hasil akhir dari produk metabolisme anaerob. ${ }^{11}$ Konsentrasi laktat darah direfleksikan sebagai keseimbangan antara produksi dan penggunaan laktat di jaringan yang memiliki nilai normal 0,5-1,8 mmol/L. Jika terjadi ketidakseimbangan antara pasokan dan kebutuhan oksigen maka dapat menyebabkan hipoksia jaringan. Hal tersebut dapat terlihat saat penggunaan otot yang berat maka piruvat akan direduksi menjadi laktat untuk menghasilkan energi yang disebut metabolisme anaerob. ${ }^{12}$ Kondisi tersebut menjadi dasar pada beberapa penelitian untuk menggunakan kadar laktat darah sebagai prediktor mortalitas. ${ }^{13}$

Suatu penelitian telah menyatakan bahwa nilai laktat statis tidak tepat untuk dijadikan prognostik dan pedoman terapi pasien kritis. ${ }^{14}$ Perhitungan laktat beberapa jam ke depan dibanding dengan nilai laktat awal disebut sebagai lactate clearance untuk melihat respons terapi dan prognostik pada pasien sepsis berat dan syok septik. Lactate clearance dihitung dengan cara: lactate initial - lactate delayed/lactate initial x $100 \% \cdot{ }^{15}$ Penelitian ini bertujuan menilai lactate clearance sebagai prediktor mortalitas pada pasien sepsis berat dan syok septik di ICU RSHS Bandung.

\section{Subjek dan Metode}

Penelitian ini merupakan studi observasional analitik dengan rancangan penelitian kohort prospektif, yaitu penelitian untuk mempelajari hasil yang dinilai di kemudian hari berdasar atas paparan yang terjadi saat penelitian dilaksanakan yang diikuti sampai hari ke-28. Subjek dipilih berdasar atas kriteria inklusi, yaitu pasien berusia 15 hingga 65 tahun, dengan gejala sepsis berat atau dengan syok septik. Kriteria ekslusi adalah pasien dengan kehamilan dan pasien sepsis berat atau syok 
septik yang telah dirawat di ICU rumah sakit lain.

Besar sampel ditentukan berdasar atas rumus penentuan besar sampel untuk penelitian uji diagnostik dengan keluaran sensitivitas dan mempertimbangkan nilai sensitivitas pemeriksaan dari penelitian sebelumnya sebesar 98\% dengan memilih taraf kepercayaan $95 \%$ dan presisi $5 \%$. Angka kejadian atau prevalensi pada penelitian sebelumnya sebesar 50\%. Dengan menggunakan $\mathrm{Z} \alpha$ yang diperoleh dari tabel distribusi normal standar, didapat nilainya sesuai untuk $\mathrm{Z} \alpha=1,96$ dan menggunakan rumus besar sampel didapatkan jumlah sampel minimal adalah 51 pasien.

Setelah mendapat persetujuan dari Komite Etik Penelitian Kesehatan Rumah Sakit Dr. Hasan Sadikin Bandung/Fakultas Kedokteran Universitas Padjadjaran, data diambil dari hasil pemeriksaan laboratorium periode bulan September hingga November 2015. Diambil data kadar laktat pada jam pertama, jam ke-24, dan nilai Acute Physiology and Chronic Health Evaluation (APACHE II) dari setiap subjek. Nilai laktat jam pertama dan jam ke-24 dihitung berdasar atas rumus lactate initial-lactate delayed/lactate initial $x$ 100\% untuk mendapatkan nilai lactate clearance. Dilakukan pengamatan keadaan pasien yang meninggal atau hidup sampai hari ke-28. Apabila pasien sebelum hari ke-28 keluar dari perawatan ICU, pengamatan tetap dilanjutkan di ruang perawatan. Nilai APACHE II merupakan baku emas sebagai alat uji nilai lactate clearance.
Tabel 1 Karakteristik Subjek Penelitian

\begin{tabular}{lc}
\hline \multicolumn{1}{c}{ Variabel } & $\mathbf{n = 5 1}$ \\
\hline Usia (tahun) & \\
Mean \pm STD & $46,76 \pm 19,51$ \\
Median & 43,000 \\
Range (min.-maks.) & $7,0-89,00$ \\
Jenis kelamin, n (\%) & \\
Laki-laki & $32(63 \%)$ \\
Perempuan & $19(37 \%)$ \\
Kategori, $n(\%)$ & $35(69 \%)$ \\
Surgical & $16(31 \%)$ \\
Medical & \\
APACHE II, n (\%) & $26(51 \%)$ \\
Nilai $\leq 17$ & $25(49 \%)$ \\
Nila $>17$ &
\end{tabular}

Hasil data dianalisis dengan uji statistik yang diawali dengan uji karakteristik. Dilakukan uji normalitas pada data numerik variable lactate clearance. Data yang tidak berdistribusi normal dilakukan uji Mann Whitney dengan nilai $\mathrm{p}<0,05$ dianggap signifikan atau bermakna secara statistika. Selanjutnya data dimasukkan pada kurva ROC untuk melihat titik potong pada nilai lactate clearance dan APACHE II. Setelah mendapatkan nilai titik potong dilakukan uji pada data kategorik melalui uji statistika Exact Fisher pada kedua kelompok variabel penelitian dengan nilai $\mathrm{p}<0,05$ dianggap bermakna secara statistika. Kemudian data dimasukkan pada tabel silang $2 \times 2$ untuk mendapatkan nilai sensitivitas, spesifisitas, nilai duga positif, nilai duga negatif, rasio kemungkinan positif, rasio

Tabel 2 Perbandingan Nilai Lactate Clearance antara Kedua Kelompok Subjek Penelitian

\begin{tabular}{lccc}
\hline \multirow{2}{*}{ Lactate clearance } & \multicolumn{2}{c}{ Kelompok } & \multirow{2}{*}{ Nilai p } \\
\cline { 2 - 3 } & Meninggal & Hidup & \\
\cline { 2 - 3 } & $\mathbf{n}=\mathbf{2 5}$ & $\mathbf{n}=\mathbf{2 6}$ & \\
\hline Mean \pm STD & $28,880 \pm 7,350$ & $56,257 \pm 13,393$ & $0,000^{* *}$ \\
Median & 29,000 & 60,000 & \\
Range (min.-maks.) & $7,00-40,00$ & $6,80-2,00$ & \\
\hline
\end{tabular}

Keterangan: untuk data numerik nilai $\mathrm{p}$ dihitung berdasar atas Uji Mann-Whitney karena data tidak berdistribusi normal. Nilai kemaknaan berdasarkan nilai $\mathrm{p}<0,05$. Tanda **menunjukkan nilai $\mathrm{p}<0,05$ artinya signifikan atau bermakna secara statistik 
Tabel 3 Perbandingan Kategori Lactate Clearance Subjek Penelitian antara Kelompok

\begin{tabular}{lccc}
\hline \multirow{2}{*}{ Lactate Clearance } & \multicolumn{2}{c}{ Kelompok } & Nilai p \\
\cline { 2 - 3 } & Meninggal (n= 23) & Hidup (n= 26) & \multirow{2}{*}{$0,000^{* *}$} \\
\hline Rendah $(<40,15)$ & 25 & 3 & \\
Tinggi $(>40,15)$ & 0 & 23 & \\
\hline
\end{tabular}

Keterangan: untuk data kategorik p dihitung berdasar atas uji statistika uji Exact Fisher. Nilai kemaknaan berdasarkan nilai $\mathrm{p}<0,05$.Nilai kemaknaan berdasarkan nilai $\mathrm{p}<0,05$. Tanda * menunjukkan $\mathrm{p}$ $<0,05$ artinya signifikan atau bermakna secara statistik

kemungkinan negatif, dan nilai akurasi. Nilai akurasi dibaca pada tabel interpretasi akurasi prediktor mortalitas.

\section{Hasil}

Data karakteristik menunjukkan bahwa dari 51 pasien yang menjadi subjek penelitian diketahui bahwa lebih banyak pasien dengan laki-laki dibanding dengan perempuan. Dari data usia dapat dilihat seluruh subjek masuk ke dalam kriteria inklusi (Tabel 1).

Nilai lactate clearance pada pasien meninggal lebih kecil dibanding dengan pasien hidup dengan perbedaan yang signifikan ( $\mathrm{p}<0,05$; Tabel 2). Kemudian, ditentukan nilai titik potong dan data dimasukkan pada kurva ROC. Nilai titik potong lactate clearance didapatkan 40,15. Pada output kurva ROC menunjukkan bahwa nilai lactate clearance mempunyai nilai diagnostik yang sangat baik karena kurva sangat jauh dari garis 50\% dan mendekati $100 \%$. Nilai AUC yang diperoleh dari metode ROC adalah sebesar 95,9\% dan nilai p sebesar 0,000 (Gambar 1).

Pada kelompok subjek yang meninggal ditemukan nilai lactate clearance yang rendah

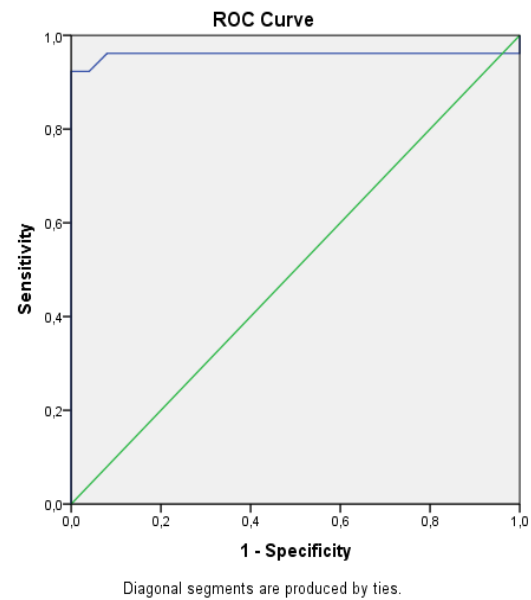

Gambar Analisis ROC pada Variabel Lactate Clearance

dan pada kelompok yang hidup memiliki nilai lactate clearance yang tinggi. Variabel kategori lactate clearance terdapat perbedaan yang bermakna dengan angka kejadian mortalitas ( $p<0,05$; Tabel 3). Nilai sensitivitas dan nilai duga positif pada variabel lactate clearance lebih tinggi dibanding dengan APACHE II dan nilai akurasi variabel lactate clarance mendekati nilai akurasi APACHE II (Tabel 4).

Tabel 4 Perbandingan Nilai Sensitivitas, Spesifisitas, Nilai Duga Positif, dan Nilai Duga Negatif Pemeriksaan Lactate Clearance dengan APACHE II

\begin{tabular}{lccccccc}
\hline \multicolumn{1}{c}{ Kategori } & Sensitivitas & Spesifisitas & NDP & NDN & RKP & RKN & Akurasi \\
\hline Lactate & 100 & 88,4 & 89,2 & 100 & $86,6 \%$ & 0 & 94,11 \\
Clearance (\%) & 96 & 96,2 & 96 & 96,2 & - & - & - \\
& - & - & - & - & - & - & 96,08 \\
APACHE II (\%) & - & - & - & - & 24,9 & 41,6 & - \\
\hline
\end{tabular}

Keterangan: NDP: nilai duga positif; NDN: nilai duga negatif; RKP: rasio kemungkinana positif; RKN: rasio kemungkinan negatif 


\section{Pembahasan}

Angka kejadian mortalitas di ICU yang disebabkan oleh sepsis berat dan syok septik masih sangat tinggi. Suatu nilai prediktor sangat memengaruhi penatalaksanaan di ICU untuk meningkatkan agresivitas terapi. Skor APACHE II dengan 12 parameter merupakan prediktor baku emas yang digunakan di ICU untuk seluruh pasien kritis. ${ }^{1,2}$ Saat terjadi kondisi sepsis berat dan syok septik, gambaran makrosirkulasi yang diukur dengan tekanan darah saja tidak cukup sebagai tanda kecukupan sirkulasi di mikroselular. Konsentrasi laktat dalam darah merupakan keseimbangan antara produksi akhir metabolisme dan eliminasi laktat. Peningkatan kadar laktat menandakan masih kurangnya sirkulasi pada jaringan mikro. ${ }^{3-5}$ Beberapa penelitian telah meneliti nilai laktat sabagai prediktor mortalitas pada pasien kritis, pasien dengan permasalahan jantung, dan pasien trauma. ${ }^{6,7}$ Namun, dengan berkembangnya ilmu pengetahuan, pemeriksaan laktat yang hanya dilakukan satu kali dianggap tidak tepat dijadikan sebagai prediktor. $^{8}$ Penelitian ini menegaskan pentingnya pemeriksaan laktat untuk melihat kecukupan sirkulasi pada jaringan mikro dan penurunan atau kenaikan kadar laktat secara berkala untuk dijadikan sebagai prediktor mortalitas pada pasien sepsis berat dan syok septik. ${ }^{5}$

Berdasar atas data numerik penelitian ini, pada variabel lactate clearance terdapat perbedaan yang bermakna $(\mathrm{p}<0,05)$ antara kelompok yang hidup dengan nilai lactate clearance 56,257 $\pm 13,393$ dan kelompok yang meninggal dengan nilai lactate clearance 28,880 $\pm 7,350$ (Tabel 2). Hasil ini sesuai dengan penelitian sebelumnya yang menyatakan nilai lactate clearance yang rendah memiliki angka mortalitas yang tinggi. Lactate clearance yang rendah menggambarkan masih terjadi gangguan sirkulasi mikro yang akan menyebabkan mortalitas.

Pada penelitian ini kurva ROC sangat jauh dari garis $50 \%$ dan mendekati garis $100 \%$. Nilai area bawah kurva yang dioperoleh dari metode ROC sebesar $0,000 \quad(<0,05)$ yang menandakan signifikan secara statistika. Nilai AUC lactae clearance sebesar 95,9\% adalah tergolong sangat kuat untuk mendiagnosis mortalitas pada 51 pasien. Dari penelitian ini juga didapatkan bahwa lactate clearance memiliki nilai spesifisitas yang cukup baik (88,4\%). Skor APACHE II memiliki spesifisitas 96,2\%. Pada penelitian ini lactate clearance memiliki nilai duga positif $89,2 \%$. Halini berarti pada kondisi lactate clearance yang rendah memberikan probabilitas pasien sepsis berat dan syok septik untuk meninggal lebih tinggi. Pada penelitian ini juga didapatkan lactate clearance memiliki nilai duga negatif 100\%. Hal ini dapat diartikan bahwa pada pasien sepsis berat dengan keadaan lactate clearance yang tinggi ( $>40 \%)$ kemungkinan untuk terjadi mortalitas lebih kecil. Tingkat akurasi lactate clearance adalah $94,11 \%$ dan nilai akurasi APACHE II adalah 96,08\%. Berdasar atas tabel interpretasi akurasi prognostik, nilai akurasi $94,11 \%$ dan $96,08 \%$ adalah termasuk sangat kuat. Hasil penelitian ini nilai lactate clearance memiliki kemampuan sebagai alat prediktor mortalitas yang sama-sama sangat kuat dengan baku emas APACHE II.

Nilai lactate clearance yang rendah $(<40 \%)$ merupakan tanda buruknya sirkulasi jaringan mikro sehingga masih dibutuhkan penatalaksanaan yang lebih agresif agar menurunkan angka mortalitas. Peningkatan lactate clearance dan penurunan nilai laktat yang signifikan merupakan tanda perbaikan sirkulasi jaringan mikro. Kegagalan penurunan nilai laktat berhubungan dengan lactate clearance yang rendah. Penurunan nilai laktat yang lama menandakan masih terjadi sirkulasi yang buruk dan masih terjadi metabolisme anaerob pada jaringan mikro sehingga akan menyebabkan kegagalan organ yang akan menyebabkan mortalitas.

\section{Simpulan}

Berdasar atas pengujian hasil penelitian dan pembahasan dapat disimpulkan bahwa lactate clearance dapat dijadikan sebagai prediktor mortalitas pada pasien sepsis berat dan syok septik di ICU RSUP. Dr. Hasan Sadikin Bandung. 


\section{Daftar Pustaka}

1. Cepinskas G, Wilson JX. Inflamatory respoonse in microvascular endothelium in sepsis: role of oxidants. J Clin Biochemi Nutr. 2008;42:175-84.

2. Riedmann Nc, Guo RF, Ward PA. The enigma of sepsis. J Crit Care Med. 2011;15:1-10.

3. Macdonald J, Galey HF, Webster NR. Oxidative stress and gene expression in sepsis. BJA. 2006;90:221-32.

4. Artero A, Zaragoza R, Nogueira JM. Epidemiology of severe sepsis and septic shock. Severe sepsis and septic shock understanding a serioous killer. Spain: Department of Medicine and Microbiology: INTECH; 2012.

5. Vallee F, Fourcade O, Marty P, Sanchez P, Samii K, Genestal M. The hemodynamic "target": a visual tool of goal directed therapy for septic patients. Clinics. 2007;62(4):447-54.

6. Georgescu AM, Sjederjesi J, Copotui Smarzam F. Predicting scores correlation in patient with septic shock - cohort study. Romanian J Anaesth Intens Care. 2014; 21(2):95-8.

7. Ladakis C, Myrianthefs P, Karabins A, Karatzas G, Dosios T, Fildsissis G, dkk. Central venous and mixed venous oxygen saturation in critically ill patients. Respiration. 2007;68(3):279-98.
8. Spronk PE, Zandstra DF, Ince C. Bench-tobedside review: sepsis is a disease of the microcirculation. Crit Care. 2008;8:462-8.

9. Kotsovolis G, Kallaras K. The role of endothelium and endogenous vasoactive substance in sepsis. Hippokratia. 2010;14(2):88-93.

10. Marik PE, Bellomo R. Lactate clearance as a target of therapy in sepsis: a flawed paradigm. Perioperative Crit Care Med. OA Crit Care. 2013;1:3-25.

11. Baker J, Nijsten MW, Jansen TC. Clinical use of lactate monitoring in critically Ill patients. Annals Intens Care. 2013;3:2-14.

12. Phypers B, Pierce JM. Lactate physiology in health and disease. Crit Care Pain. 2006;6:128-35.

13. Kruse O, Gunnet N. Blood lactate as a predictor for in hospital mortality in patients admitted acutely to hospital: a systematic review. Scand J Trauma Resucitation Emerg Med. 2011;19:74-82.

14. Vernon C, LeTourneau JL. Lactic acidosis: recognition, kinetics and associated oprognosis. Crit Care Clin. 2006;10:25583.

15. Marty P, Roquilly A, Vallee F, Luzi A, Ferre F, Fourcade 0 , dkk. Lactate clearance for death prediction in severe sepsis or septic shock patients during the first 24 hours in Intensive Care Unit: an observational study. Annals Intens Care. 2013;3:3-27. 